\title{
THE EFFECT OF DIOXIN ON LOW BIRTH WEIGHT IN SOUTHERN WEST VIRGINIA BETWEEN 1955 - 1969
}

Frank H Annie, $\mathrm{PhD}^{1}$, Chris K Uejio, $\mathrm{PhD}^{2}$, Sarah Embrey ,PharmD ${ }^{3}$, Alfred Tager MD $^{1}$

${ }^{1}$ Charleston Area Medical Center Health Education and Research Institute

${ }^{2}$ The Florida State University ,Department of Geography

10 Bellamy Building, Room 323113 Collegiate Loop PO Box 3062190

11 Tallahassee, FL 32306-2190

${ }^{3}$ University of Charleston, School of Phramcy 2300 MacCorkle Ave SE

14 Charleston, WV 25304

${ }^{1}$ For Correspondence

Frank H Annie, PhD, MPA, MA

Research Scietntist

Charleston Area Medical Center Health Education and Research Institute

3200 MacCorkle Ave Charleston, WV 25304

Phone: 304-388-9921

23 Fax: 304-388-9929

Email: Frank.h.annie@ camc.org WEST VIRGINIA BETWEEN 1955 - 1969

Original Research

31 Authors have no competing interests to declare 


\section{ABSTRACT}

\section{Objective:}

38 The effect of low birth weight as a result of dioxin-based exposure has been investigated through

39 the existing literature, but the debate on exact point source and production is still debated. The

40 Monsanto factory located in Nitro, West Virginia produced Agent Orange from 1948 - 1969.

\section{Methods:}

42 The vital statistics registry from the state of West Virginia of Kanawha county and Putnam

43 county West Virginia. The production of dioxin and 2-4-5T was obtained from the legal files

44 from (Civil Action No. 04-C-465) and the expert witness of Dr. Bruce Bell. In order to

45 understand this relationship a time series analysis was conducted to compare 2-4-5T and dioxin

46 and low-birthweight in Kanawha County and Putnam County, West Virginia.

\section{Results:}

48 The results suggest dioxin within Kanawha county had a suggestive relationship associated with

49 dioxin production and low birthweight from 1948- 1969 had a suggestive relationship of $(p=$

50 0.042). The comparison county of Putnam had no statistically significant relationship between

51 low birthweight and dioxin production $(p=0.203)$. Agent Orange $(2-4-5 t)$ was also considered

52 and measured within the counties of Kanawha and Putnam Counties, within these two counties

53 no statistically significant relationship was observed.

\section{Conclusions:}

55 In conclusion the association between dioxin and low birthweight still requires more research but

56 this analysis illustrates that there appears to be a suggestive relationship that exists within

57 Kanawha County, West Virginia as related to the production of and effect of the by-product of

58 dioxin. 
medRxiv preprint doi: https://doi.org/10.1101/2020.09.22.20199059; this version posted September 23, 2020. The copyright holder for this

\section{Introduction}

60 Preterm birth (i.e., fewer than 37 weeks of gestation) and slower prenatal development produce

61 low-birth-weight infants (1). Newborns weighing 2,500 grams or less are generally classified as

62 low-birth-weight infants and may have slower growth rates, slower cognitive development, and

63 reduced levels of maternal antibodies to fight infections $(2,3,4)$. Low birth weight may also

64 contribute to long-term complications, including chronic heart disease, chronic kidney disease,

65 and a higher risk of developing diabetes later in life (3). An increasing number of low-birth-

66 weight newborns correspondingly increases health care costs for households and health care

67 networks $(5,6)$.

The causes of low birth weight have been determined to be multifactorial and include

69 exposures such as maternal alcohol use, smoking, infection during pregnancy, drug abuse,

70 maternal age less than 17 years or greater than 35 years, and race $(7,8,9,10)$. The mother's health

71 status can also play a significant role in the development process, as any related illnesses can

72 alter the development process of the fetus (11). Other external variables that have been examined

73 include toxic chemical exposures such as dioxins, lead, mercury, and PCBs (11).

74 Current literature indicates a possible link between low birth weight in newborns and

75 dioxin exposure $(12,13,14)$. Dioxins are a class of chemical by-products generated in various

76 manufacturing processes, such as the production of rubbers and synthetic plastics. At the

77 Monsanto plant in Nitro, West Virginia, which is the focus of this study, dioxins were generated

78 during the production of sodium 2,4,5-Trichlorophenate (NaTCP) $(15,16)$. The estimated amount

79 of dioxin produced from 1948 to 1969 was approximately 0.47 parts per million (17). Depending

80 on the subclass, dioxin exposures below $0.1-1.0$ parts per trillion may not cause adverse health

81 effects (18). 
medRxiv preprint doi: https://doi.org/10.1101/2020.09.22.20199059; this version posted September 23, 2020. The copyright holder for this

The primary avenue of human exposure is through consuming contaminated foods (19);

83 however, in populations with consistent dioxin exposure, dermal absorption may also be an

84 important exposure route. The pathophysiology of how the body processes dioxin differs from

85 person to person, but the substance is metabolized and broken down within the liver and

86 absorbed into fatty cells. The rate of breakdown depends on the subclass of dioxin and the

87 amount of fat within the body (20). Dioxin's chemical structure is similar to some hormones and

88 may bind to cellular aryl hydrocarbon receptors and immediately affect human health (19).

89 Dioxin can remain in the tissue for many years depending on fat content (20). Exposure at

90 sufficient levels may cause health problems such as cancer, male reproduction toxicity, female

91 reproduction toxicity, effects on unborn fetuses, skin disorders, and other metabolic and

92 hormonal abnormalities $(19,21)$. This study builds upon previous work where areas that

93 produced or have high dioxin concentrations also report elevated rates of low birth weight

94 compared to neighboring counties $(22,6)$. Some studies suggested that excessive exposure over a

95 short period may also negatively impact birth outcomes (23).

96 This study focuses on a point dioxin exposure source in a United States community with

97 a lower dioxin production (of approximately 0.47 parts per million) than Vietnam. During the

98 Vietnam War, larger dioxin exposures caused adverse health outcomes these exposure quantities

99 could range from 0.001 to 1.0 parts per million depending on the level of contamination in the

100 region (19). This study investigates the relationship between Kanawha County's and neighboring

101 Putnam County's low birth weight rates and the Monsanto plant dioxin production from 1955 to

102 1969. Other dioxin studies focus primarily on indirect dioxin and PCB exposures from

103 consuming food (e.g., fish) and low newborn birth weight (24). This study also examines the

104 synchronous relationship between dioxin production and low birth weight whereas other studies 
medRxiv preprint doi: https://doi.org/10.1101/2020.09.22.20199059; this version posted September 23, 2020. The copyright holder for this

105 examine the lingering health effects of existing dioxin contamination. Furthermore, this study

106 separately compares dioxin production against the proportion of low-birth-weight children while

107 controlling for independent risk factors such as median household income.

108

109 Methods

110 Study Area

111 The study area includes the residents of Kanawha County and Putnam County, West Virginia.

112 Kanawha County consists of Nitro, Charleston (the state capitol), and over 100 towns and small

113 cities located near the Monsanto plant (see Figure 1). From 1948 to 1969, the U.S. government

114 commissioned chemical companies such as Monsanto to produce Agent Orange in Nitro, West

115 Virginia. By 1969, the U.S. government had discontinued using the substance for any large-scale

116 military operations in Vietnam, and Monsanto subsequently halted Agent Orange production at

117 its Nitro plant. To provide a comparison, the study tests whether Kanawha County dioxin

118 production is related to low birth weight in Putnam County. This county was compared because

119 of its geographical proximity to Kanawha County as well as the low birthweight data was also

120 available from Putnam County as well. No additional point sources of pollution were in the

121 Putnam County area (see Figure 1).

124 Data

125 This study's primary data sources include birth records from the State of West Virginia Vital

126 Statistics Registry and a court document from the Putnam County Court of West Virginia, the

127 former of which provided the annual total number of births and low-birth-weight infants along 
medRxiv preprint doi: https://doi.org/10.1101/2020.09.22.20199059; this version posted September 23, 2020. The copyright holder for this

128 with the proportion of low-birth-weight infants in the study counties. The study involved subjects

129 born between 1955 and 1969 who were issued a new birth certificate in Kanawha or Putnam

130 County. The Vital Statistics Registry did not compile a database of birth records before 1955.

131 Moreover, due to a structure fire, additional documents from 1970 to 1985 were destroyed or

132 damaged and could not be obtained as they no longer existed. The registry did not include those

133 who resided in the county but those who went to a medical facility outside the county to give

134 birth.

135 The second data source is the Putnam County Court document against the Agricultural

136 Division of Monsanto. From 1948 through 1969, this report estimated dioxin production loss to

137 the environment through burning, sewer loss, production, and waste disposal, which was

138 estimated to be 10,000 pounds. Dr. Bruce Bell, an expert witness for the plaintiff, reported the

139 estimates during the court case discovery period for the plaintiff (Civil Action No. 04-C-465).

140 Dr. Bell's estimates were generated from the Monsanto plant blueprints and sales receipts. The

141 Calwell Practice PLLC, Law and Arts Center West in Charleston, West Virginia, commissioned

142 the report.

143 This study also considered statewide annual median household income provided by the

144 United States Census Bureau. Median household income was adjusted and standardized for

145 inflation from 1955 to 1969 . Income may be a surrogate marker for access to health care, health

146 literacy, smoking, and alcohol usage, all of which may influence low birth weight (25). In fact,

147 the correlation between household income and low birth weight has been established within the

148 literature (26). The study could not control for annual rates of smoking and alcohol usage, as

149 these were unavailable for the study period and region. 
medRxiv preprint doi: https://doi.org/10.1101/2020.09.22.20199059; this version posted September 23, 2020. The copyright holder for this

\section{Statistical Analysis}

152 For each county, we created separate multiple variable time series models to relate dioxin

153 production to low birth weight while controlling for median household income. Epidemiology

154 commonly uses time series analysis to describe a short-term exposure to a health outcome (27).

155 The technique compares rates in the same study population over time, which naturally controls

156 for slowly changing low birth weight confounders.

157

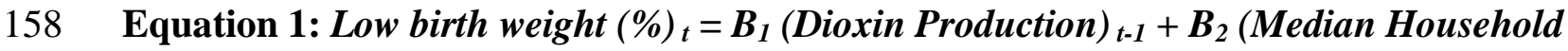

159 Income $)_{t}+B_{3}(\text { year })_{t}+e\left(0, \sigma^{2}\right)$

In Equation 3, low birth weight is the percentage of low-birth-weight infants, and the

163 and long-term temporal trends (study year). To further account for the gestational lag between

164 exposure and birth, each exposure variable was lagged one year. For example, exposure in 1955

165 would influence birth weight in 1956; the subscript $t$ thus refers to the year sequence beginning

166 at 1956 , or 1955 for $t-1$. The time series model assumptions were then verified with standard

167 diagnostic tests. A histogram confirmed that the residuals were normally distributed.

168 Furthermore, autocorrelation and partial autocorrelation functions verified that the time series did

169 not contain significant residual temporal autocorrelation. Finally, Akaike and Bayesian

170 Information Criterion measured the time series model fit.

\section{Results}


174 Table 1. Results of the time series analysis on dioxin production and low birth weight in

175 Kanawha County, West Virginia.

176

177

\begin{tabular}{|c|c|c|c|c|c|}
\hline Variable & Coefficient & $\begin{array}{l}\text { Standard } \\
\text { Error }\end{array}$ & $\mathbf{T}$ & $P>t$ & $\begin{array}{l}\text { (95\%) Confidence } \\
\text { Interval }\end{array}$ \\
\hline Dioxin Production & 0.0411 & 0.0178 & 2.31 & 0.042 & $0.0018-0.0804$ \\
\hline Median Income & -4.528 & 1.1938 & -3.48 & 0.005 & $-6.7805--1.5251$ \\
\hline Year & 0.2457 & 0.122 & 2.19 & 0.051 & $-0.0012-0.4928$ \\
\hline
\end{tabular}

178

179 Table 2. Results of the time series analysis on dioxin production and low birth weight in

180 Putnam County, West Virginia.

\begin{tabular}{|c|c|c|c|c|c|}
\hline Variable & Coefficient & $\begin{array}{l}\text { Standard } \\
\text { Error }\end{array}$ & $\mathbf{T}$ & $\mathbf{P}>\mathbf{t}$ & $\begin{array}{l}\text { (95\%) Confidence } \\
\text { Interval }\end{array}$ \\
\hline Dioxin Production & 0.0053 & 0.0039 & 1.35 & 0.203 & $-0.0033-0.0140$ \\
\hline Median Income & -0.0001 & 0.0003 & -0.83 & 0.424 & $-0.0001-0.0004$ \\
\hline Year & 0.1827 & 0.2767 & 0.66 & 0.522 & $-0.4203-0.7857$ \\
\hline
\end{tabular}

181

182

183

Tables 1 and 2 report the regression results from the best fitting time series models. Both

184 models fulfilled the time series model assumptions. The Kanawha County regression model

185 tested the association between annual dioxin production and the percentage of low-birth-weight 
medRxiv preprint doi: https://doi.org/10.1101/2020.09.22.20199059; this version posted September 23, 2020. The copyright holder for this preprint (which was not certified by peer review) is the author/funder, who has granted medRxiv a license to display the preprint in perpetuity. All rights reserved. No reuse allowed without permission.

186 infants (see Table 1). Based on the beta coefficient, every 10 pounds of dioxin produced an

187 increased incidence of low birth weight by $0.41 \%$. Moreover, each $\$ 10,000$ USD increase in

188 household income decreased the incidence of low birth weight by $4.5 \%(p=0.005)$. Figure 2

189 plots the relationship between observed and time series-fitted low birth weight for dioxin 190 production.

191 Table 1 reports the regression results of the best fitting time series model of Putnam

192 County. Dissimilar to Kanawha County's regression table, this one indicates no significant

193 results associated with the acute exposure of dioxin and low birth weight. Figure 3 plots the

194 relationship in the county between the observed acute dioxin exposure and the time series-fitted

195 low birth weight time series analysis.

196

197 Discussion

198 This study found a suggestive relationship between an increase of dioxin from the production of

199 Agent Orange (2,4,5-T) (see Appendix) and an acute increase of low birth weight in Kanawha

200 County, West Virginia $(P=0.042)$. Individuals with lower socioeconomic status consistently

201 tend to have infants with lower birth weights $(25,28,29,30,31$,$) . A comparison county, Putnam$

202 County, located west of Kanawha County, was analyzed during the same period. Results found

203 that there was no association between low birth weight and the production of dioxins $(P=0.203)$

204 in Putnam County. This outcome provides additional evidence that Kanawha County dioxin

205 exposure is not a proxy for an unmeasured time-varying exposure.

206 Our study results suggest that dioxin production may increase the incidence of low birth

207 weight over time. Again, this study builds upon previous work where areas that produced or have

208 high dioxin concentrations also report elevated rates of low birth weight compared to 
medRxiv preprint doi: https://doi.org/10.1101/2020.09.22.20199059; this version posted September 23, 2020. The copyright holder for this preprint (which was not certified by peer review) is the author/funder, who has granted medRxiv a license to display the preprint in perpetuity. All rights reserved. No reuse allowed without permission.

neighboring counties $(32,33)$. These previous two studies examined exposure related to the

210 consumption of food or working in dioxin-related industries. For instance, the Rylander 1995

211 study assessed the high use of contaminated food from the (Sweden) Baltic Sea that was

212 associated with an increased risk of low birth weight in the community; the Rylander 2000 study

213 further supported the link between the intake of dioxin from fish and an increased risk of low

214 birth weight. However, neither study estimated a range of dioxin exposure levels that

215 corresponded to the risk of low birth weight infants. Further studies such as the Tsikimori 1968-

2162004 work explored the link between exposure to rice contaminated with Yusho oil and preterm

217 births and induced abortions in Japan, researching the period from 1968 to 2004, when dioxin

218 exposure had ceased. The study found that women exposed to dioxins had a twofold increase in

219 preterm pregnancy and an increase in induced abortions five times greater than the baseline

220 number.

221 In the study area and period, dioxin exposures were estimated at 0.47 parts per million

222 (Civil Action No. 04-C-465). This level of exposure is generally similar to that found in

223 international studies of dioxin exposure and adverse newborn outcomes. Karmaus's 1995 study,

224 conducted in Germany, more precisely measured dioxin exposures and low birth weight:

225 newborns with median concentrations of dioxin in blood samples of 0.5 parts per million

226 demonstrated an average decrease of 175 grams and 2 centimeters from their birth measurements

227 compared to nonexposed infants. Relatedly, studies suggest acute dioxin exposures of

228 approximately 0.3 parts per million increase the risk of urinary tract birth defects in France (32).

229 Our studies are partially consistent with studies on laboratory animals, specifically rat

230 studies illustrating reduced size of offspring (34,35). Dioxin binds to the fetus's cellular aryl

231 hydrocarbon receptor (AhR), which activates a gene that influences growth hormones. Dioxins 
medRxiv preprint doi: https://doi.org/10.1101/2020.09.22.20199059; this version posted September 23, 2020. The copyright holder for this

232 can act at the AhR due to their structural similarity to other endogenous hormones in the human

233 body. This occurrence in turn causes random growth variations that lead to the reduced

234 formation and growth of an infant (36). Research on AhR receptors confirms a correlation

235 between dioxin-linked gene modification and chronic effects such as a compromised immune

236 system and soft tissue damage (37).

237 The primary mechanism of dioxin exposure is consuming food contaminated with fine

238 dioxin and other chemical powders that circulate in the area. The dioxin was released into the

239 water and air of the surrounding community through waste disposal and incineration practices

$240(38,39)$. The fine dioxin powder adheres to clothing and can accumulate inside buildings and

241 cause adverse health outcomes over time or have a more immediate effect $(40,41)$.

242 This section describes the limitations of the population-based study, which used existing

243 secondary data sources to investigate the relationship between dioxin production and low birth

244 weight. The study also used a time series analysis to account for as many limitations as possible.

245 These models control for other low birth weight risk factors that change slowly over time;

246 however, the study design cannot control for the effects of other chemicals in the study area with

247 similar production schedules to dioxins. For example, the DuPont factory in Dunbar, West

248 Virginia, was five miles upstream from the Monsanto site, and data regarding the production of

249 substances at this plant could not be obtained for this study.

250 Other noteworthy issues concern births that occurred at institutions outside Kanawha

251 County and the time when birth certificates were issued. For instance, it should be noted that the

252 study period covers the time before the interstate highway system was constructed. It therefore

253 may have been difficult to reach the next closest hospital outside the patient's home county, and

254 for this reason, relatively few patients would have been misclassified into the incorrect county. A 
medRxiv preprint doi: https://doi.org/10.1101/2020.09.22.20199059; this version posted September 23, 2020. The copyright holder for this

255 time lag may have also occurred between home birth and birth registration, as only children born

256 in a hospital would have been issued a birth certificate immediately. Conducting the time series

257 analysis at yearly intervals would minimize — but not eliminate—birth timing misclassification

258 error.

259 Our study relied on testimony from a single source to estimate chemical production and

260 used median household income as a surrogate for health status and behaviors such as alcohol and

261 tobacco usage. Controlling for these risk factors would strengthen the study results, but historical

262 local alcohol and tobacco use rates were not systematically collected. We examined national

263 alcohol and tobacco use trends over time to test whether they exhibit a similar pattern to dioxin

264 production. Smoking prevalence was increasing during the mid-1950s, before the study period;

265 during the study period, it remained relatively constant until the mid-1970s, with a gradual

266 downward trend when bans on smoking commercials were introduced and smoking cessation

267 began to be promoted (42). A National Institute of Alcohol Abuse and Alcoholism study

268 illustrates that alcohol consumption increased across the study period (42). Increased alcohol

269 consumption could lead to increased low birth weight depending on levels of consumption (43).

270 If regional statistics mirrored national alcohol and tobacco consumption trends, these risk factors

271 did not mimic the dioxin production schedules.

272

\section{Conclusion}

274 This study illustrates that a higher exposure level of 0.47 parts per million can influence low

275 birth weight within the surrounding area. Furthermore, the findings of this study reveal a

276 suggestive relationship ( $p=0.042)$ as compared to low birth weight within Kanawha County,

277 West Virginia. A comparison county, Putnam County, was included to provide further evidence 
medRxiv preprint doi: https://doi.org/10.1101/2020.09.22.20199059; this version posted September 23, 2020. The copyright holder for this preprint (which was not certified by peer review) is the author/funder, who has granted medRxiv a license to display the preprint in perpetuity. All rights reserved. No reuse allowed without permission.

278 of an association between dioxin exposure and low birth weight, but this test provided no

279 statistical significance $(P=0.203)$. Dioxins and dioxin-like substances are prevalent within our

280 environment even now, and the findings of this study suggest that there might be an effect.

281 Further research is needed to understand the continued effect within the environment,

282 specifically in the Appalachian Region. Based on existing literature, dioxin is still within the

283 environment of Kanawha County, West Virginia; at high levels and with a multidecade half-life,

284 it will remain in the environment for years to come. 


\section{Appendix}

Table A1. Results of the time series analysis of 2,4,5-T production and low birth weight.

\begin{tabular}{|l|l|l|l|l|l}
\hline Variable & Coefficient & $\begin{array}{l}\text { Standard } \\
\text { Error }\end{array}$ & T & P $>$ t & $\begin{array}{l}(\mathbf{9 5 \%}) \text { Confidence } \\
\text { Interval }\end{array}$ \\
\hline 2,4,5-T Production & $\mathbf{0 . 0 0 1 9}$ & $\mathbf{0 . 0 0 0 9}$ & 1.95 & $\mathbf{0 . 0 7 7}$ & $\mathbf{- 0 . 0 0 0 2 - 0 . 0 0 4 1}$ \\
\hline Median Income & $\mathbf{- 4 . 0 9 2 9}$ & $\mathbf{1 . 2 5 2 5}$ & $\mathbf{- 3 . 2 7}$ & $\mathbf{0 . 0 0 7}$ & $\mathbf{- 6 . 8 4 9 7 - - 1 . 3 3 6 2}$ \\
\hline Year & $\mathbf{0 . 2 4 9 2}$ & $\mathbf{0 . 1 1 7 8}$ & $\mathbf{2 . 1 2}$ & $\mathbf{0 . 0 5 8}$ & $\mathbf{- 0 . 0 1 0 0 - 0 . 5 0 8 6}$ \\
\hline
\end{tabular}

$2932,4,5-\mathrm{T}$ production $(p=0.077$ ) (see Table A1): Based on the beta coefficient, every 10,000

294 pounds of 2,4,5-T produced increased the incidence of low birth weight by $0.19 \%$. Similar to the

295 dioxin model, higher median household income significantly decreased the proportion of low-

296 birth-weight children $(p=0.007)$. For every $\$ 10,000$ increase in median household income, low

297 birth weight incidence decreased by 4.0\%. Figure A1 plots the relationship between observed

298 and time series-fitted low birth weight for 2,4,5-T production. The model demonstrates a

299 supportive relationship, but certain years (e.g., 1968 and 1969) do not exhibit a strong

300 relationship between production and low birth weight. 
medRxiv preprint doi: https://doi.org/10.1101/2020.09.22.20199059; this version posted September 23, 2020. The copyright holder for this preprint (which was not certified by peer review) is the author/funder, who has granted medRxiv a license to display the preprint in perpetuity.

1. Kim, Hye Eun, et al. "Trends in Birth Weight and the Incidence of Low Birth Weight and Advanced Maternal Age in Korea between 1993 and 2016." Journal of Korean Medical Science, vol. 34, no. 4, Jan. 2019, p. e34, doi:10.3346/jkms.2019.34.e34.

2. Aarnoudse-Moens, C. S. H., et al. "Meta-Analysis of Neurobehavioral Outcomes in Very Preterm and/or Very Low Birth Weight Children." Pediatrics, vol. 124, no. 2, Aug. 2009, pp. 717-28, doi:10.1542/peds.2008-2816.

3. Hack, M., et al. "Long-Term Developmental Outcomes of Low Birth Weight Infants." The Future of Children / Center for the Future of Children, the David and Lucile Packard Foundation, vol. 5, no. 1, 1995, pp. 176-96, doi:10.2307/1602514.

4. Larroque, B. "Developmental Sequelae of Very Premature Children at School Age. [French]." Journal de Gynecologie Obstetrique et Biologie de La Reproduction, vol. 33, no. 6 I, Oct. 2004, pp. 475-86, http://ovidsp.ovid.com/ovidweb.cgi?T=JS\&CSC=Y\&NEWS=N\&PAGE=fulltext\&D=emed6\&AN=200 4443791\%5Cnhttp://202.120.227.56:3210/sfxlcl3?sid=OVID:embase\&id=pmid:\&id=doi:\&issn=0 $\underline{368-2315 \& \text { isbn }=\& \text { volume }=33 \& \text { issue }=6+1 \& \text { spage }=475 \& \text { pages }=475-}$ $486 \&$ date $=2004 \&$ title $=$ Journal+de+Gyn.

5. Russell, R. B., et al. "Cost of Hospitalization for Preterm and Low Birth Weight Infants in the United States." Pediatr, vol. 120, doi:10.1542/peds.2006-2386.

6. Rylander, Lars, et al. "Decreased Birth Weight in Infants Born to Women with a High Dietary Intake of Fish Contaminated with Persistent Organochlorine Compounds." Scandinavian Journal of Work, Environment \& Health, vol. 21, no. 5, 2011, pp. 368-75, doi:10.5271/sjweh.51.

7. Als, Heidelise. "Individualized Developmental Care for the Very Low-Birth-Weight Preterm Infant." Jama, vol. 272, no. 11, 2011, p. 853, doi:10.1001/jama.1994.03520110033025.

8. Clemans-Cope, Lisa, et al. "Pregnant Women with Opioid Use Disorder and Their Infants in Three State Medicaid Programs in 2013-2016." Drug and Alcohol Dependence, vol. 195, Feb. 2019, pp. 156-63, doi:10.1016/j.drugalcdep.2018.12.005.

9. De Vita, Maria Vittoria, et al. "Malnutrition, Morbidity and Infection in the Informal Settlements of Nairobi, Kenya: An Epidemiological Study." Italian Journal of Pediatrics, vol. 45, no. 1, Jan. 2019, p. 12, doi:10.1186/s13052-019-0607-0.

10. Ponticelli, Claudio, and Gabriella Moroni. "Fetal Toxicity of Immunosuppressive Drugs in Pregnancy." Journal of Clinical Medicine, vol. 7, no. 12, Dec. 2018, p. 552, doi:10.3390/jcm7120552.

11. Rahman, Mohammad L., et al. "Investigating Causal Relation between Prenatal Arsenic Exposure and Birthweight: Are Smaller Infants More Susceptible?" Environment International, vol. 108, 2017, pp. 32-40, doi:10.1016/j.envint.2017.07.026.

12. Baba, T., et al. "Intrinsic Function of the Aryl Hydrocarbon (Dioxin) Receptor as a Key Factor in Female Reproduction." Molecular and Cellular Biology, vol. 25, no. 22, 2005, pp. 10040-51, doi:10.1128/mcb.25.22.10040-10051.2005.

13. Chen, Ichen, et al. "Indole-3-Carbinol and Diindolylmethane as Aryl Hydrocarbon (Ah) Receptor Agonists and Antagonists in T47D Human Breast Cancer Cells." Biochemical Pharmacology, vol. 51, no. 8, 1996, pp. 1069-76, doi:10.1016/0006-2952(96)00060-3.

14. Detmar, Jacqui, et al. " Fetal Growth Restriction Triggered by Polycyclic Aromatic Hydrocarbons Is Associated with Altered Placental Vasculature and AhR -Dependent Changes in Cell Death ." American Journal of Physiology-Endocrinology and Metabolism, vol. 295, no. 2, 2008, pp. E51930, doi:10.1152/ajpendo.90436.2008. 
medRxiv preprint doi: https://doi.org/10.1101/2020.09.22.20199059; this version posted September 23, 2020. The copyright holder for this preprint (which was not certified by peer review) is the author/funder, who has granted medRxiv a license to display the preprint in perpetuity. All rights reserved. No reuse allowed without permission.

15. Udell, Jon G. "Can Attitude Measurement Predict Consumer Behavior?" Journal of Marketing, vol. 29, no. 4, 1965, pp. 46-50.

16. Strum, J. C. Progress Report Nitro Plant Technical Services, Reduction of TDD in NaTCP - Building 92. 1969.

17. Zina Bibb, et al. v. Monsanto, et al., Civil Action No. 04-C-465, filed on December 17, 2004, against Monsanto Company and Pharmacia Corporation

18. USEPA Office Of Research Development. "Estimating Exposure to Dioxin-Like Compounds, Vol II Properties, Sources, Occurrence and Background Exposures." Usepa, 1994.

19. Lorber, Matthew, Donald Patterson, Janice Huwe, and Henry Kahn. "Evaluation of Background Exposures of Americans to Dioxin-like Compounds in the 1990s and the 2000s." Chemosphere, vol. 77, no. 5, 2009, pp. 640-51.

20. Pirkle, William H., and Thomas C. Pochapsky. "Considerations of Chiral Recognition Relevant to the Liquid Chromatography Separation of Enantiomers." Chemical Reviews, vol. 89, no. 2, 1989, pp. 347-62.

21. DeVito, M., and L. S. Birnbaum. "Toxicology of the Dioxins and Related Chemicals." Dioxins and Health, 1994.

22. Govarts, Eva, et al. "Birth Weight and Prenatal Exposure to Polychlorinated Biphenyls (PCBs) and Dichlorodiphenyldichloroethylene (DDE): A Meta-Analysis within 12 European Birth Cohorts." Environmental Health Perspectives, vol. 120, no. 2, 2012, pp. 162-70, doi:10.1289/ehp.1103767.

23. Ding, Tianbing, Melinda McConaha, Kelli L. Boyd, Kevin G. Osteen, and Kaylon L. Bruner-Tran. "Developmental Dioxin Exposure of Either Parent Is Associated with an Increased Risk of Preterm Birth in Adult Mice." Reproductive Toxicology, vol. 31, no. 3, 2011, pp. 351-58.

24. Giesy, J. P., et al. "Effects of Chronic Dietary Exposure to Environmentally Relevant Concentrations to 2,3,7,8-Tetrachlorodibenzo-p-Dioxin on Survival, Growth, Reproduction and Biochemical Responses of Female Rainbow Trout (Oncorhynchus Mykiss)." Aquatic Toxicology, vol. 59,2000, pp. 35-53.

25. Villar, José, and JoséM. Belizán. "The Relative Contribution of Prematurity and Fetal Growth Retardation to Low Birth Weight in Developing and Developed Societies." American Journal of Obstetrics and Gynecology, vol. 143, no. 7, 2016, pp. 793-98, doi:10.1016/0002-9378(82)900126.

26. Garrett, B. E., Dube, S. R., Trosclair, A., Caraballo, R. S., Pechacek, T. F., et al. "Cigarette Smoking-united States, 1965-2008." MMWR Surveill Summ, vol. 60, no. 1, 2011, pp. 109-13.

27. Bhaskaran, Krishnan, Antonio Gasparrini, Shakoor Hajat, Liam Smeeth, and Ben Armstrong. "Time Series Regression Studies in Environmental Epidemiology." International Journal of Epidemiology, vol. 42, no. 4, 2013, pp. 1187-95.

28. Chu, J. R., Hagan, J., \& Hair, A. An Investigation into the Association Between Socioeconomic Factors with Growth and Developmental Outcomes in Premature Low Birth Weight Infants. 2018.

29. Foster, H. W., et al. "Intergenerational Effects of High Socioeconomic Status on Low Birthweight and Preterm Birth in African Americans." Journal of the National Medical Association, vol. 92, no. 5, 2000, pp. 213-21, http://www.pubmedcentral.nih.gov/articlerender.fcgi?artid=2640563\&tool=pmcentrez\&render type=abstract.

30. Krieger, N., et al. "Choosing Area Based Socioeconomic Measures to Monitor Social Inequalities in Low Birth Weight and Childhood Lead Poisoning: The Public Health Disparities Geocoding Project (US)." Journal of Epidemiology and Community Health, vol. 57, no. 3, 2003, pp. 186-99, doi:10.1136/jech.57.3.186. 
medRxiv preprint doi: https://doi.org/10.1101/2020.09.22.20199059; this version posted September 23, 2020. The copyright holder for this preprint (which was not certified by peer review) is the author/funder, who has granted medRxiv a license to display the preprint in perpetuity. All rights reserved. No reuse allowed without permission.

31. Pattenden, S., et al. "Inequalities in Low Birth Weight: Parental Social Class, Area Deprivation, and 'lone Mother' Status." Journal of Epidemiology and Community Health, vol. 53, no. 6, 1999, pp. 355-58, doi:10.1136/jech.53.6.355.

32. Cordier, Sylvaine, et al. "Maternal Residence near Municipal Waste Incinerators and the Risk of Urinary Tract Birth Defects." Occupational and Environmental Medicine, vol. 67, no. 7, 2010, pp. 493-99, doi:10.1136/oem.2009.052456.

33. Karmaus, W., and N. Wolf. "Reduced Birthweight and Length in the Offspring of Females Exposed to PCDFs, PCP, and Lindane." Environmental Health Perspectives, vol. 103, no. 12, 1995, pp. 1120-25, doi:10.1289/ehp.951031120.

34. Rier, S. E., Martin, D. C., Bowman, R. E., Dmowski, W. P., \& Becker, J. L. (1993). Endometriosis in rhesus monkeys (Macaca mulatta) following chronic exposure to 2, 3, 7, 8-tetrachlorodibenzop-dioxin. Fundamental and applied toxicology, 21(4), 433-441.

35. Murray, Noreen E., Sandra A. Bruce, and K. Murray. "Molecular Cloning of the DNA Ligase Gene from Bacteriophage T4: II. Amplification and Preparation of the Gene Product." Journal of Molecular Biology, vol. 132, no. 3, 1979, pp. 493-505.

36. NEBERT, DANIEL W., et al. "Role of the Ah Receptor and the Dioxin-Inducible [Ah] Gene Battery in Toxicity, Cancer, and Signal Transduction." Annals of the New York Academy of Sciences, vol. 685, no. 1, 1993, pp. 624-40, doi:10.1111/j.1749-6632.1993.tb35928.x.

37. Sinkkonen, Seija, and Jaakko Paasivirta. "Degradation Half-Life Times of PCDDs, PCDFs and PCBs for Environmental Fate Modeling." Chemosphere, vol. 40, no. 9-11, 2000, pp. 943-49, doi:10.1016/S0045-6535(99)00337-9.

38. Eljarrat, Ethel, et al. "Effects of Sewage Sludges Contaminated with Polychlorinated Dibenzo-pDioxins, Dibenzofurans, and Biphenyls on Agricultural Soils." Environmental Science and Technology, vol. 31, no. 10, 1997, pp. 2765-71, doi:10.1021/es9610601.

39. Manz, A., et al. "Cancer Mortality among Workers in Chemical Plant Contaminated with Dioxin." The Lancet, vol. 338, no. 8773, pp. 959-64, doi:10.1016/0140-6736(91)91835-I.

40. Brezner, Esther, Joseph Terkel, and Albert S. Perry. "The Effect of Aroclor 1254 (PCB) on the Physiology of Reproduction in the Female Rat--I. Comparative Biochemistry and Physiology. C." Comparative Pharmacology and Toxicology, vol. 77, no. 1, 1984, pp. 65-70.

41. Lucier, G. W., et al. "Ingestion of Soil Contaminated with 2,3,7,8-Tetrachlorodibenzo-p-Dioxin (TCDD) Alters Hepatic Enzyme Activities in Rats." Toxicological Sciences, vol. 6, no. 2, 1986, pp. 364-71, doi:10.1093/toxsci/6.2.364.

42. Ramstedt, Mats. "Alcohol and Fatal Accidents in the United States-A Time Series Analysis for 1950-2002." Accident Analysis and Prevention, vol. 40, no. 4, pp. 1273-81, doi:10.1016/j.aap.2008.01.008.

43. Mills, J. L., Graubard, B. I., Harley, E. E., Rhoads, G. G., \& Berendes, H. W. (1984). Maternal alcohol consumption and birth weight: How much drinking during pregnancy is safe?. Jama, 252(14), 1875-1879.

\footnotetext{
Figure Legend
} 
454 1. Figure 1. Kanawha County, West Virginia, which includes the county seat of Charleston, 455 West Virginia (the state capitol), had a census of 252,925 in 1960. The area is defined by a 456 massive chemical industry as well as the coal industry. Kanawha County also includes

457 large banks, hospitals, and universities. Putnam County, which includes the county seat of 458 Winfield and the largest city of Hurricane, had a census of 23,561 in 1960. Putnam County included several towns and later became a suburban area between Kanawha County and Cabell County, West Virginia.

2. Figure 2. Time series analysis on low birth weight compared to dioxin production in Kanawha County, West Virginia, from 1955 to $1969(P=0.042)$.

3. Figure 3. Time series analysis on low birth weight compared to dioxin production in Putnam County from 1955 to $1969(P=0.203)$.

1A. Time series analysis of low birth weight $2,4,5-T$ production. 
medRxiv preprint doi: https://doi.org/10.1101/2020.09.22.20199059; this version posted September 23, 2020. The copyright holder for this preprint (which was not certified by peer review) is the author/funder, who has granted medRxiv a license to display the preprint in perpetuity. All rights reserved. No reuse allowed without permission.

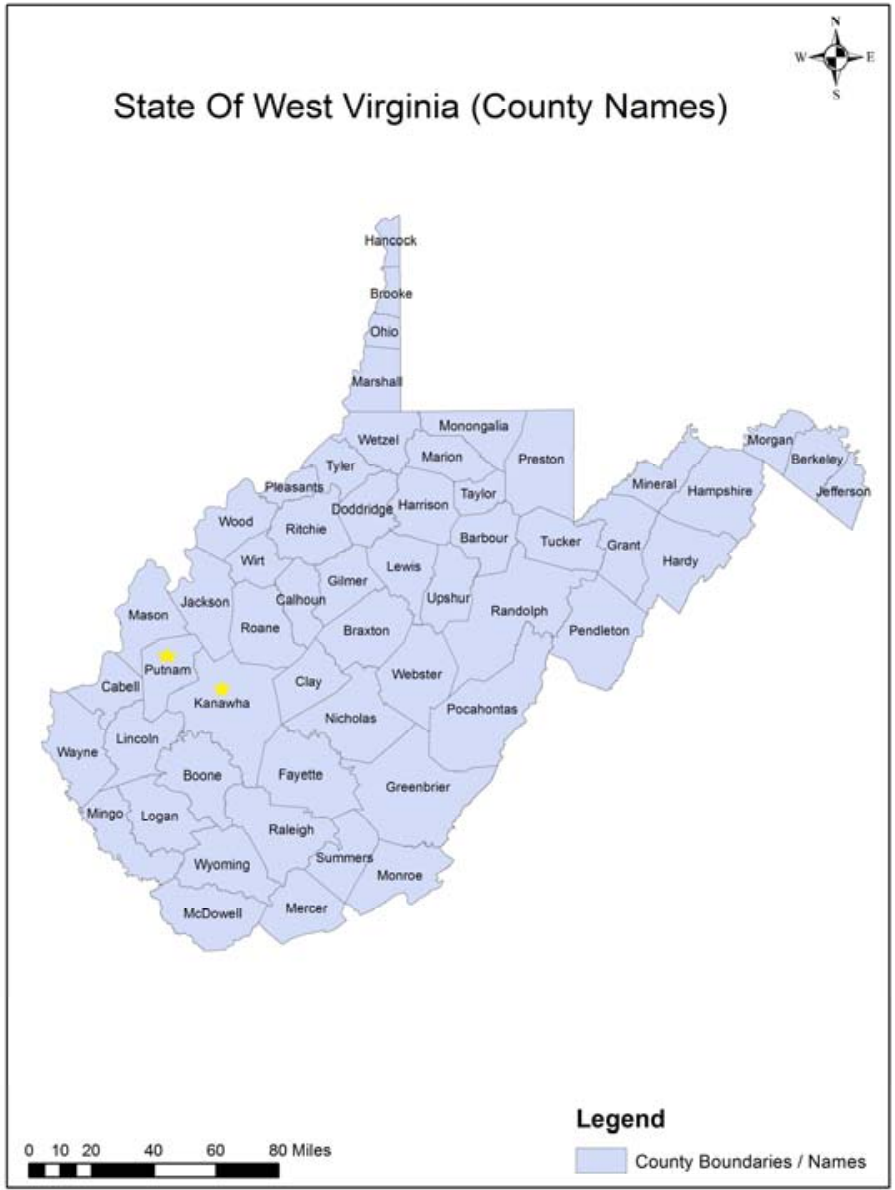

499 is located at CAMC Health Education and Research Institute 


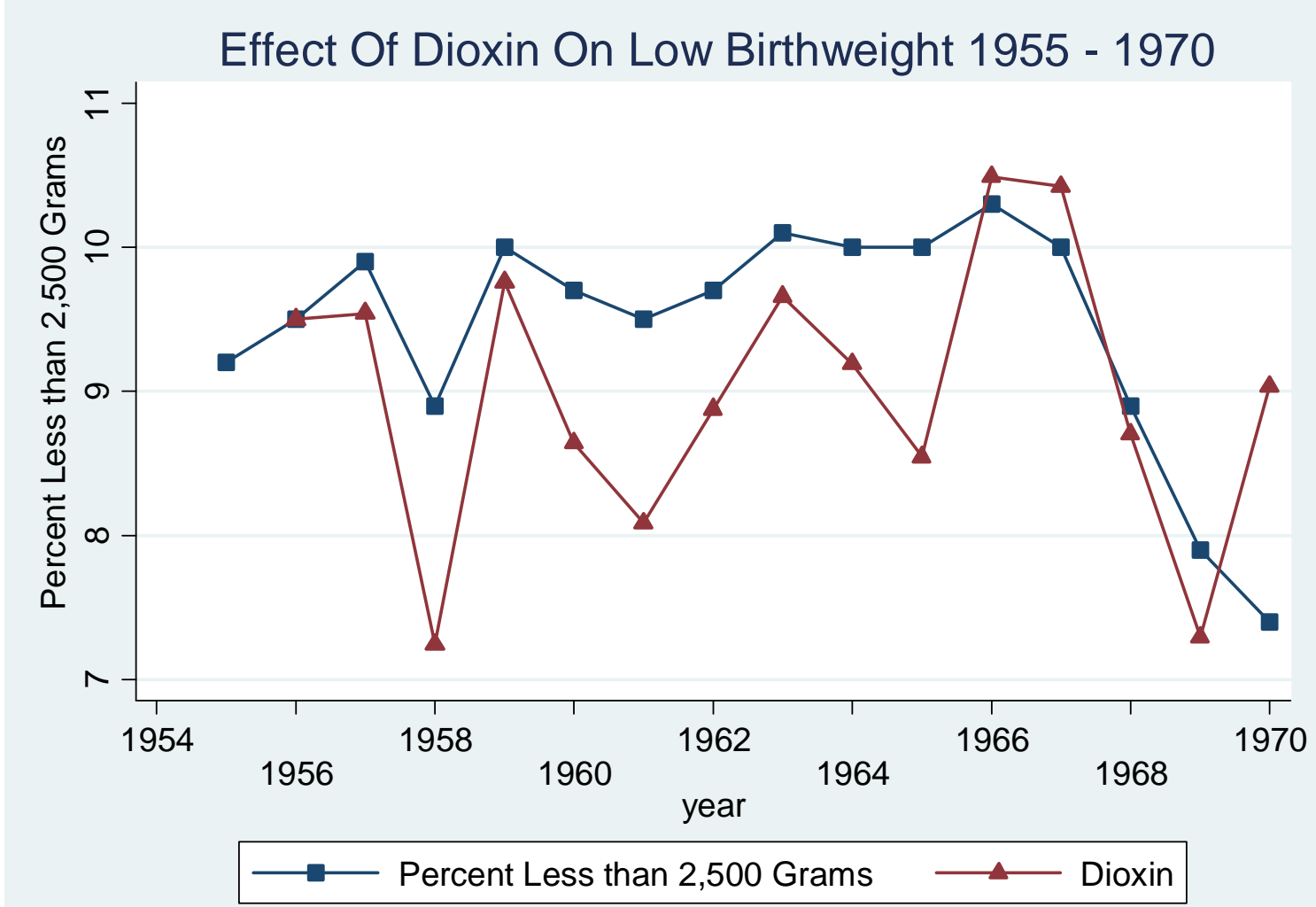

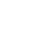




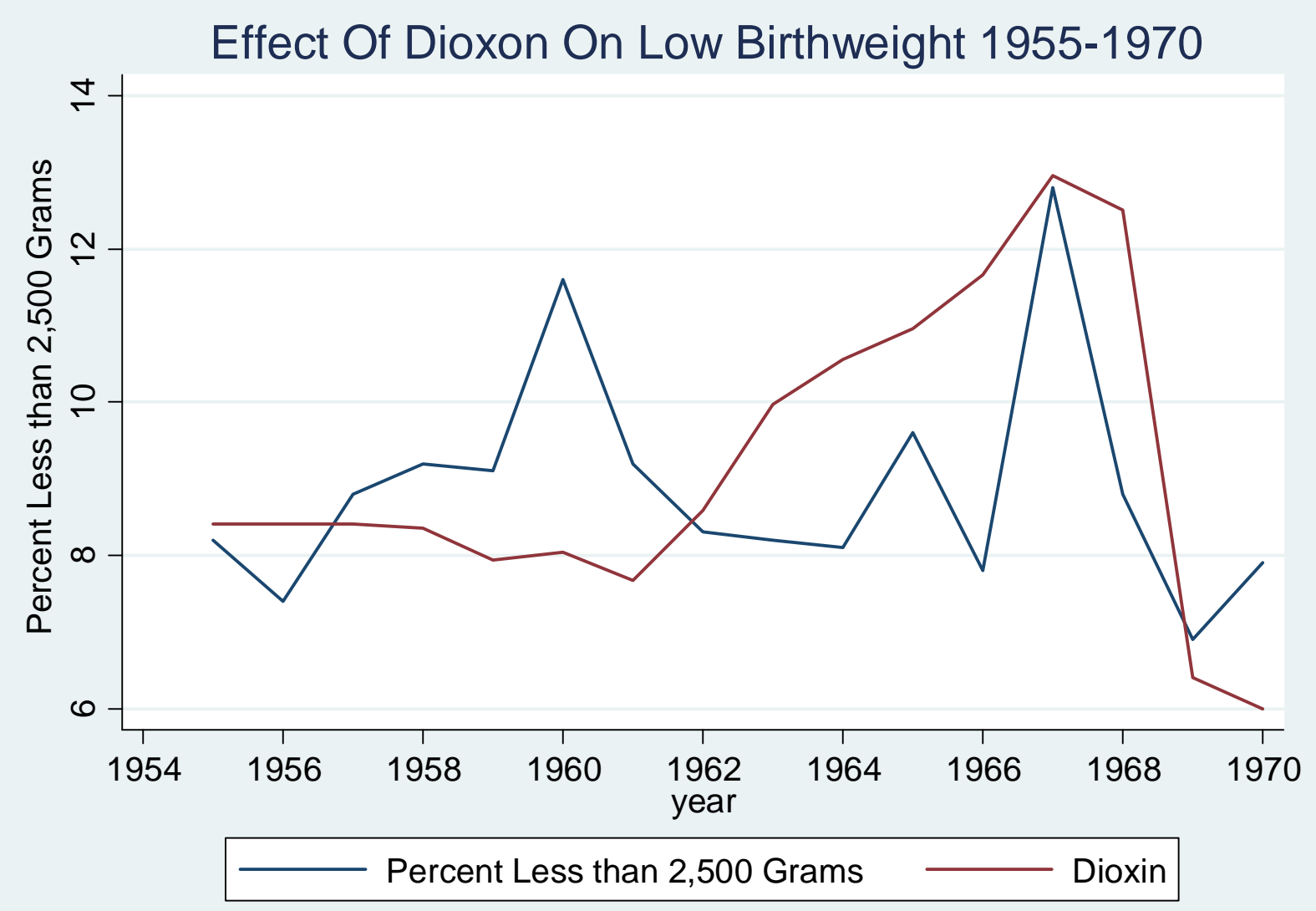




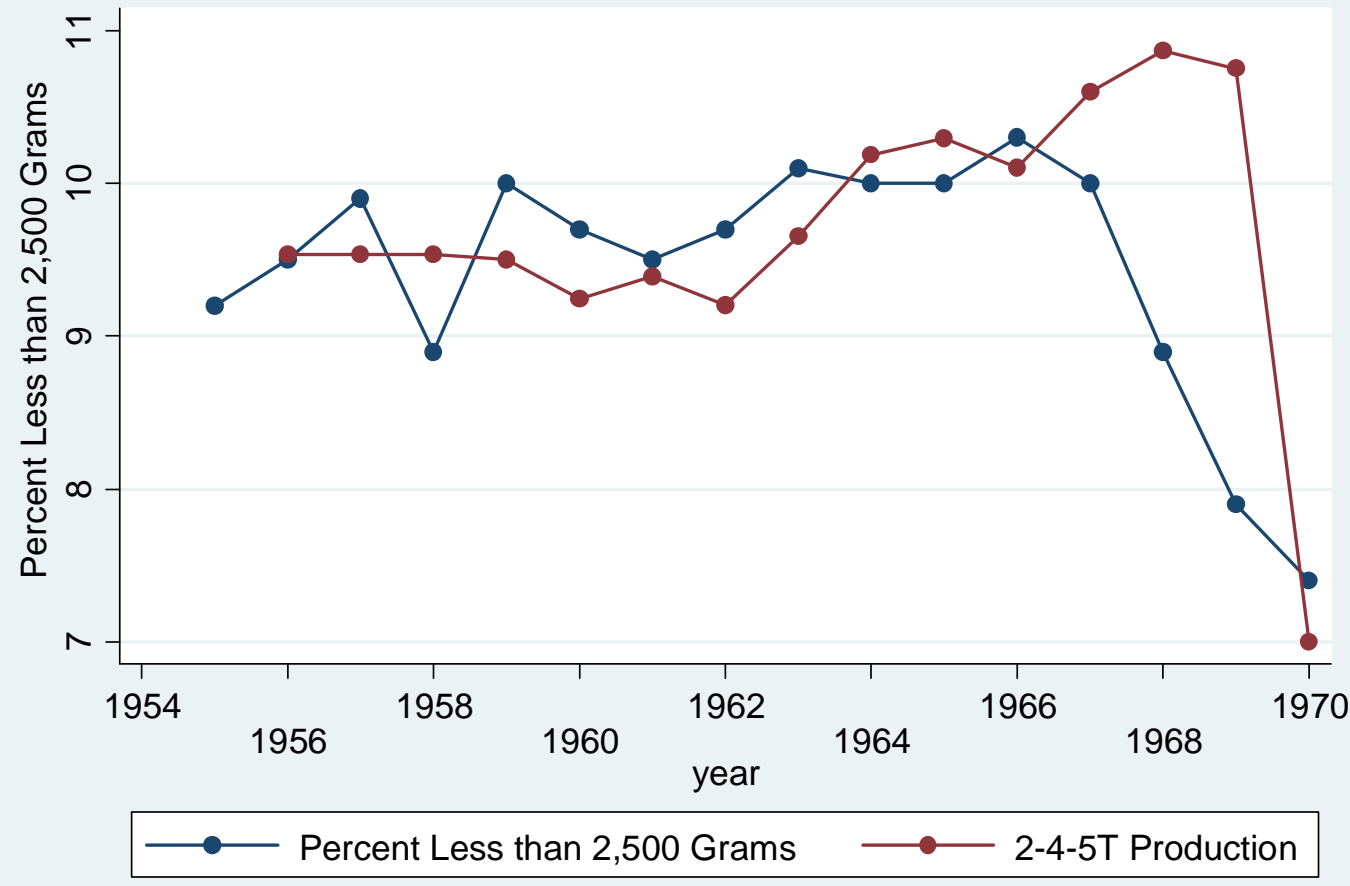

